This item was submitted to Loughborough's Research Repository by the author.

Items in Figshare are protected by copyright, with all rights reserved, unless otherwise indicated.

\title{
Examining the effectiveness of fashion marketing on social media: An experiment on influencer's reputation, post type, and online eWOM valence
}

PLEASE CITE THE PUBLISHED VERSION

http://gfmcproceedings.net/html/sub3_01.html

\section{VERSION}

AM (Accepted Manuscript)

\section{PUBLISHER STATEMENT}

This work is made available according to the conditions of the Creative Commons Attribution-NonCommercialNoDerivatives 4.0 International (CC BY-NC-ND 4.0) licence. Full details of this licence are available at: https://creativecommons.org/licenses/by-nc-nd/4.0/

\section{LICENCE}

CC BY-NC-ND 4.0

\section{REPOSITORY RECORD}

Meng, Jie, and Yik Shun. 2019. "Examining the Effectiveness of Fashion Marketing on Social Media: An Experiment on Influencer's Reputation, Post Type, and Online Ewom Valence". figshare.

https://hdl.handle.net/2134/38068. 


\title{
EXAMINING THE EFFECTIVENESS OF FASHION MARKETING ON SOCIAL MEDIA: AN EXPERIMENT ON INFLUENCER'S REPUTATION, POST TYPE, AND \\ ONLINE EWOM VALENCE
}

Jie Meng, Loughborough University, London, U.K.

Yik Shun Ma, Oxford Brookes University, Oxford, U.K.

\begin{abstract}
This paper investigates the three key determinants of digital marketing and consumer behaviour associated with fashion marketing on social media. The aim of the research is to explore the aspects of Instagram via the R.E.A.N. framework and the purchase intention in fashion consumption. The conceptual model \& hypothesis were tested using structural equation modelling. A non-probability sampling with 280 millennials Instagram's users participated. The empirical results indicate that the account reputation was found to be a significant predictor of REAN engagement. It also concluded that all engagement levels on REAN model have significant relationships toward customer buying intention among eight cases. This study proposes a new conceptual model which can be defined as a stepping stone or future research in the field of fashion. The model is validated in other social networking sites and industries. The findings provide valuable information that can be used in a social media marketing strategy in the contemporary business world.
\end{abstract}

\section{Keywords}

REAN model

Account reputation

Producer-generated content

User-generated content

eWOM 


\section{INTRODUCTION}

Social media marketing is soaring, yet within this tide, apparel advertising on social media (e.g., Facebook, Instagram) and its effectiveness remain under-explored in the knowledge domain. In particular, the Instagram is the latest photo-sharing social media platform which has brought a new stage of customer engagement. Customer engagement and conversion effectiveness on social media, remained at the core of digital marketing communication research. Confronted with a pending conclusion of what determines the effectiveness of social media ads, there awaits more endeavours to reveal the causality of social media marketing influence.

This study has investigated the effect on engagement levels of REAN model and purchase intention using Instagram. This article has shown the increasing importance of social media marketing and customer engagement by highlighting the number of marketing studies (e.g. Kim \& Ko, 2012; Kerpen, 2015). Previous studies lack explanations of the use of Instagram and REAN model. In fact, no research has been conducted on the relationships between these three variables on Instagram via REAN model and purchase intention. This study undertook to determining the major factors involved in Instagram. It is important to state that this research addresses the research gaps. This research contributes to the literature regarding millennials' engagement levels on Instagram and purchases intentions. Overall, this study has revealed significant differences between account reputation and REAN model and enriched the marketing knowledge by linking the actionable social media marketing antecedents with the expected customer conversion outcomes.

\section{THEORETICAL BACKGROUND}

\section{Factors Impacting Social Media Advertising Effectiveness}

This research is built on two streams of concepts, i.e., information trustworthiness (such as account reputation and content type) and information adequacy (such as eWOM valence and volume).

One of the factors that impact the credibility of online message or influence is the source characteristics (Miles 2014). Ohanian (1990) defined credibility as a communicator's positive characteristics that able to influence receiver acceptance of certain information (Ohanian 1990). The account reputation will affect the perception of trustworthiness and credibility of the brand. Based on the functions of Instagram, the businesses with a good reputation should get the verified badge for the account to be recognizable on Instagram. These accounts normally have a greater number of followers. Meanwhile, a bad reputation on the Instagram account has no verification and fewer followers. Miles (2014) mentioned that the credibility of companies in relation to the size as well as the number of followers. The account profile on Instagram represents the brand image and company's reputation. Instagram has the uniquely powerful source of tremendous credibility and exposure. To understand the effect of account reputation on customer engagement, the study proposes the Hypothesis 1: The account reputation has a significant effect on the effectiveness of social media. 
The content is another major feature of social media communication. Instagram posts have rich content attributes with images, videos, hashtags and no restricted in word length (Lee, Hosanagar and Nair 2014). Marketers should develop a content strategy to consider how to tailor the content on Instagram to appeal to customers. It is summarized that five different types of pictures to drives customer engagement: customer-centric photos; employeecentric photos; instagram contest photos; product photos and photos with bloggers (Hemley 2013). It is important to create a mix of different types of pictures for the posts on Instagram, including two main categories of content: producer-generated content (PGC) and usergenerated content (UGC) (Bahtar and Muda 2016, Jonas 2010).

PGC is classified as "advertiser-controlled" (Rodgers and Thorson 2000) because the advertisement is initiated and managed by the company. The common formats of PGC consist banner, company official website/blog and email marketing (Jonas 2010). PGC is relatively in informative content including price and product features. Customers can receive more accurate and relevant information from PGC. The product-related aspects are used in optimising the customers' purchase decision.

On the other hand, social media is considered as platforms that allow the creation and exchange of user-generated content (Kaplan and Haenlein 2010), which is normally created outside of professional routines and practices (OECD 2017). Compared to PGC, the advertising features of UGC is users own and self-controlled information. The common formats of UGC include third-party blogs, forums and wikis, and content sharing sites (Jonas 2010). The growth is UGC is rapid. Many businesses launch the post content with the products' benefits by using endorsement (Verhellen, Dens and Pelsmacker 2013). UGC is relative with persuasive content. Lee et al. (2014) stated that persuasive content as emotional and philanthropic can increase engagement instead of informative content(Lee et al. 2014). The persuasive contents involving the endorsement of a product can gain customer trust and good-will for the brands. Driven by UGC, the capacity of social media in helping fashion brands to engage potential customers to increase the online presence. UGC has the ability to influence the brands as well as customer behaviours(Goldsmith and Horowitz 2006). For fashion, UGC seems more about the outfit of the day and how to mixand-match.

The studies emphasize that UGC is a more credible source of information than that of PGC because consumers trust the content generated by other users regarding brands and products (Jonas 2010, Verhellen et al. 2013, Bahtar and Muda 2016). Customers prefer peer experiences and recommendations rather than commercial and official content (Mir and Rehman 2013, Jonas 2010). UGC is proven to be more trustworthy, useful and unbiased. With the emergence of social media, Online content created by endorsers in a creative effort is a significant element in marketing (Dennhardt 2014). The endorsement is the most influential party in the social networking platform.

Differences between firm-created and user-generated social media communication suggested that firm-created social media communication affected brand attitude while usergenerated social media communication influenced on brand equity and brand attitude. The study is mainly on the brand, instead of the customers' view. A successful post on social media marketing is to create relevant content to attract target audiences. It is the key to 
measure the types of content that contribute to generating customer engagement. Hence, this study proposes the Hypothesis 2: The type of post content has a significant effect on the effectiveness of social media.

The concept of word-of-mouth (WOM) valence was first researched and characterised as person-to-person oral communication in a non-commercial way toward a brand, product or service. WOM is a general concept of interpersonal communication with the recommendation from customers' experiences (Buttle 1998). WOM is defined as informal communication between private parties to evaluate products and service (Anderson 1998). WOM has the power of personal referral on consumer behaviour. Buttle (1998) stated that WOM has influenced awareness, expectation, perceptions, attitudes, behavioural intentions and customer behaviour. As a marketing tool in a massive degree, WOM is more powerful of WOM to raise awareness is higher than advertising. Moreover, WOM is an important influential factor in consumer buying decision (Keller 2007). The importance of WOM is highly related to consumers' attitudes and brands' characteristics (Jeon and Baeck 2016). With the technological development of the Internet, the traditional WOM communication has been extended to digitalised, which known as electronic word-of-mouth (eWOM). eWOM is also well-known as 'online referrals' in online forums, blogs and social networking sites (Huete-Alcocer 2017). Customers tend to use social media platforms to express their thoughts and opinions on various topics and product according to the personal experience.

Both volume and valence of WOM are important sources of information which have a significant impact on consumer behaviour and product sales. With electronic communication, online reviews by internet users have become an information flow with rapidly spread (Chen et al. 2011). eWOM is categorised as a positive, neutral or negative statement when customers shared through the Internet. eWOM is the key aspects in the social media marking (Armelini and Villanueva 2011). eWOM provides influential information sources on the Web (Hsu, Lin and Chiang 2013). eWOM is an important facilitator in influencing consumer perceptions and purchase behaviour of potential customers (Feick and Price 1987). Customers believed that eWOM is more trustworthy than other information sources. Herold (2015) examined the influences of eWOM on customers purchasing decision. eWOM has a significant effect on customers' purchase decision and intention to buy (Lee and Lee 2009, Hsu et al. 2013, Herold 2015). Smith (2012) reviewed that customers trust a review from peers twelve times more than descriptions from the brand itself. The results indicated that online reviews are more outweighed than the brand itself (Smith 2012). Social media marketing is more effective to attract millennials and motivate customer engagement. Anderson (1998) claims satisfied customers engage more in greater WOM. Both positive and negative perceived reviews are very important to affect consumer attitude and buying intention through the creation of impression (Purnawirawan, Pelsmacker and Dens 2012). The study of Kimmel and Kitchen (2014) who applauds Anderson to prove that positive eWOM has a greater impact than negative eWOM (Kimmel and Kitchen 2014). On the other hand, there are comparative studies claimed that the impact of negative reviews is more influencing than positive reviews (Chen et al. 2011, Sparks and Browning 2011, Arndt 1967). 
Due the limited time and resources, it is difficult to generate and compare the volume of WOM. The overall review for a given product can be predominantly positive or negative. The characteristics of positive reviews are pleasant, vivid or novel descriptions of experiences whereas negative reviews included complaining and unpleasant descriptions (Anderson 1998). The valence of WOM has become an important factor in shaping consumer engagement levels (Sparks \& Browning, 2011). The factors influencing consumer engagement in eWOM in social media are becoming critical. The extent to which previous research has moved towards investigating the significant influence of eWOM on the brand and customers is therefore somewhat limited. This paper proposes the Hypothesis 3: The valence of word-of-mouth has a significant effect on the effectiveness of social media.

\section{REAN Framework}

For the outcome, REAN is a web analytic framework (i.e., 'Reach', 'Engage', 'Activate' and Nurture') and evaluating tool for the online activities with visualisations of a website's performance structure (Jackson 2009). The findings of Coursaris et at. (2013) proved the actions following the REAN model have a positive impact on web performance (Coursaris et al. 2013). REAN is a simple powerful framework to plan and analyse the complex sequence of inter-related and multichannel marketing activities that are needed to build and nurture a customer relationship. Jackson (2009) believe the REAN model is more concreted measurement strategy to give a visualised overview of a website and measure marketing activities. Xavier Blanc stated the model is not just applied SEM, web and CRM but also all about creating an experience and educational materials (Jackson 2016). It is a more quantitative model for mapping a digital marketing channel strategy. The REAN model is commented to be the most relevant model to plan and measure website performance and activities.

The REAN model can be defined as "every business website is affected by REAN. They all need to reach their potential customers, then they need to engage with them, activate them and finally, you need to nurture them, in other words, encourage them to come back" (Jackson 2009). REAN model represents the customer engagement levels are the key research area contributing to the understanding of consumer behaviour. It aims to move a customer from awareness stage to action, then to be a loyal customer. In order to predict future customer behaviour, the ways of matching their engagement level seem necessary (Kim \& Ko, 2012). While social networking sites are replacing the tradition website, REAN model can be adapted to measure the performance of Instagram. 
Figure 1: The definitions of four factors in REAN model

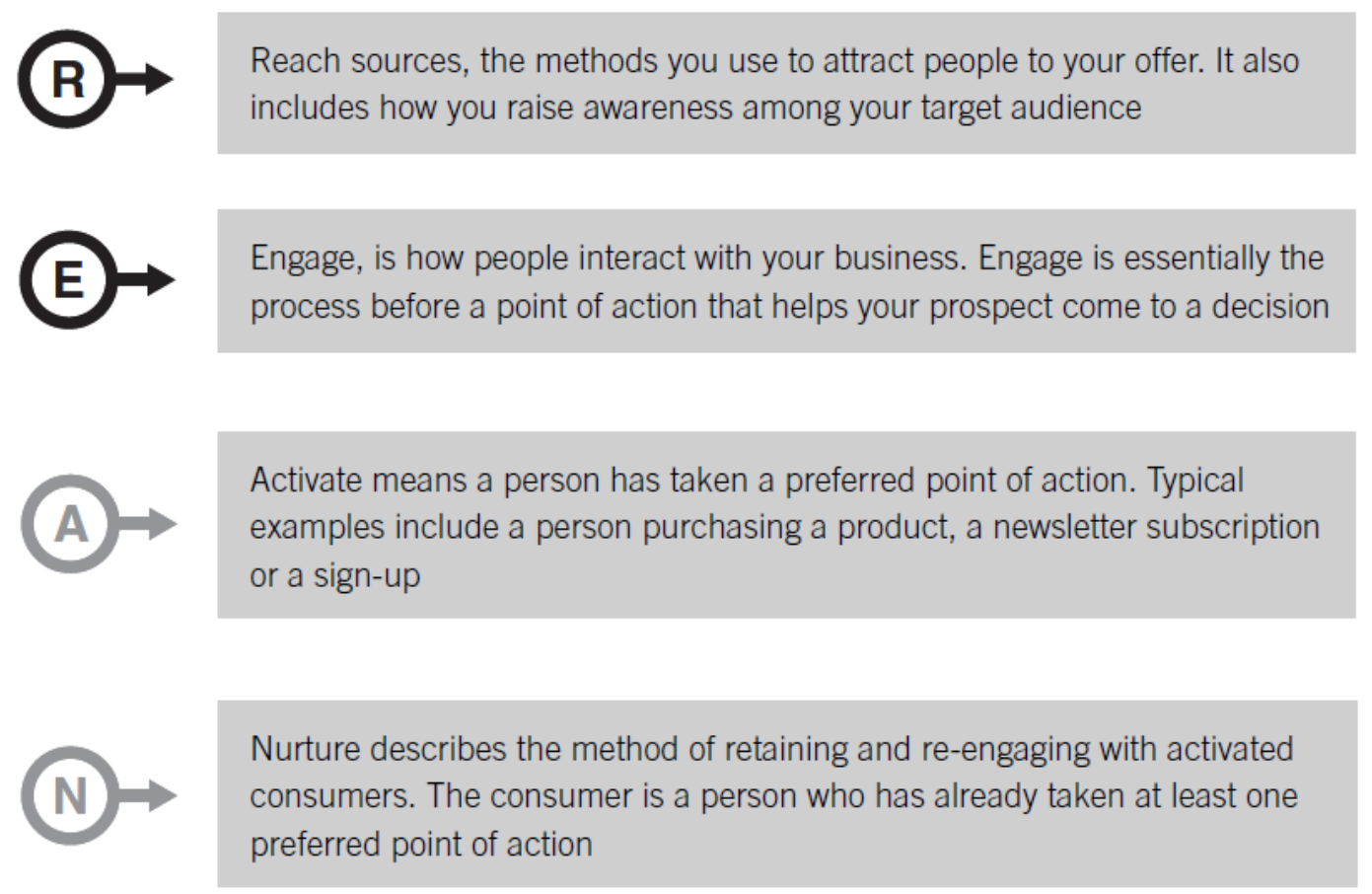

Source: Jackson, Cult of Analytics: Driving online marketing strategies using web analytics, p.26, 2009

"Reach" refers to "the set of activities needed to raise prospects' attention for your brand, product or service." (Jackson, 2016). It measures the methods using to attract an audience and how to raise awareness among the target audiences. Reach is described as the initial step to generate traffic and get attention to the platform such as search engine optimisation (SEO) (Visser and Weideman 2011). Nowadays, social media marketing provides the greatest opportunity to reach consumers, for example, Flickr, Viral and YouTube. Jackson (2009) stated that the brand awareness is highly related to the reach. Reach is the phase of required to generate traffic to the website. The current study seeks to investigate the performance on Instagram with a fashion brand toward millennials. Reach is the first stage to drive customers' attention in order to create conversion. The Instagram account plays an important role in this stage to create brand awareness. Account profile is the first recognition of the brand on Instagram (Instagram 2017). Apart from that, customers will also consider the creativity of the post content.

The "Engage" is defined as "the gradual, typically multi-channel, often recursive set of activities needed to engage the prospects you just won"(Jackson 2016). Engagement is the way of interaction between customers and businesses. Engage is essentially the process to help customers' prospect for decisions before a point of action (Jackson 2009) which plays an important role in the social media marketing including 'participation' and 'involvement'(Brodie et al. 2011). The popularity of social media leads to consumer 
participation and engagement in an easier way. Engagement is a key aspect of measurement for determining the effectiveness of social media marketing. Engage is an orientation phase which includes how people interact with your business online (Jackson 2016). The common key performance indicators (KPIs) of engagement are the percentage of bounce rate, duration, pages per visit and segmented conversion goals such as 'contact us; and downloads (Jackson 2009). Engagement includes the behaviours in word-of-mouth, recommendations and writing reviews, which are the functions of likes and comments on Instagram (Lee et al. 2014). The consumers' reactions towards post content will be assessed in order to evaluate the differences between PGC and UGC.

The third component "Activate" is defined as the action in the manner consumers desired which is the most important elements of REAN model (Jackson 2009). Activate is classified as the purchase phase which means a preferred point of action was taken (Jackson 2016). This is also known as a conversion with "call to action"(Jackson 2016). Activation KPIs are related to product purchase, a newsletter subscription or a sign-up. In the case of Instagram, sharing the post with others is the way of activation because there is no function for the actual purchase.

The last component "Nurture" is defined as "the method of retaining and re-engaging with activated consumers" (Jackson 2009). Nurture is classified as the evaluation phase and the stage of retaining and re-engaging with activated consumers. The KPIs of Nurture are repeat visits, logins, community engagement: recency and frequency(Jackson 2016). In particular, KPIs are the way of understanding the measurement of activities. It is important to change first-time customers into repeat customers. In the case of Instagram, nurturing and growing a vibrant fan base is significant for the brands. After following the IG account, nurturing the relationship with customers by providing added value which is an enhancement to retain their loyalty. Nurturing means the capability to get users to return and become loyal to the brand. The activities including CRM marketing, online support, follow-up email and membership are needed to nurture the customer relationship (Jackson 2009). However, the concept of loyalty is different in social media networking site like Instagram. This study will focus the continuous engagement with the brand on the Instagram such as follow the account to be part of the community.

Social media marketing strategy encapsulates the various optimization actions according to the REAN model. Taking everything into account, the REAN model appears to be the most relevant in this study with social media marketing on Instagram to cover the key research questions and. Finding the connection with the different stages of REAN model towards purchase intention is the problem that this study seeks to investigate. The relationship has been built through discussion, therefore this study proposes Hypothesis 4: The effectiveness of social media has a significant effect on purchase intention.

\section{Buying Intention}

Defined as the willingness to buy products and/or service (Kim and Ko 2012), purchase intention is an attitudinal variable in future contribution to a brand. Several studies highlighted the difference between purchase intention and actual purchase (Namias 1959, Rimal, Fletcher and McWatters 1999, Wee 2014). The information on social media can 
change the customers' attitude on intended purchase (Nunes et al. 2018). Customers are using social media to search for information and seek previous reviews/comments before the decision to purchase, especially on Instagram. Generally, the customers' purchase intention serves as one of the consequences of social media marketing to measure the extent of messages' impacts on social media users instead of checking the clickstream data from the Instagram (Prasertsith, Kanthawongs and Kanthawongs 2015). Thus, this study focuses on exploring the purchase intentions instead of actual purchase behaviour. Purchase intention can be adopted as a dependent variable to represent the level of user engagement following the REAN framework in both theoretically and methodologically.

To sum up, previous studies have been successful in moving towards reaching practical guidelines in a somewhat limited way. From the literature reviewed, herein, it is evident that further research is required into the features of Instagram: account reputation, post types and eWOM, the engagement level via the REAN model and the prediction of purchase intention.

\section{METHOD}

By combining an array of factors in social media communication, the factor of Information source (Instagram account identity), content (post type), and social influence of the surrounding (EWOM's valence) and their impacts on the social media marketing performance via the reach, engagement, activation and nurture procedure are studied.

Figure 2: The Conceptual Model

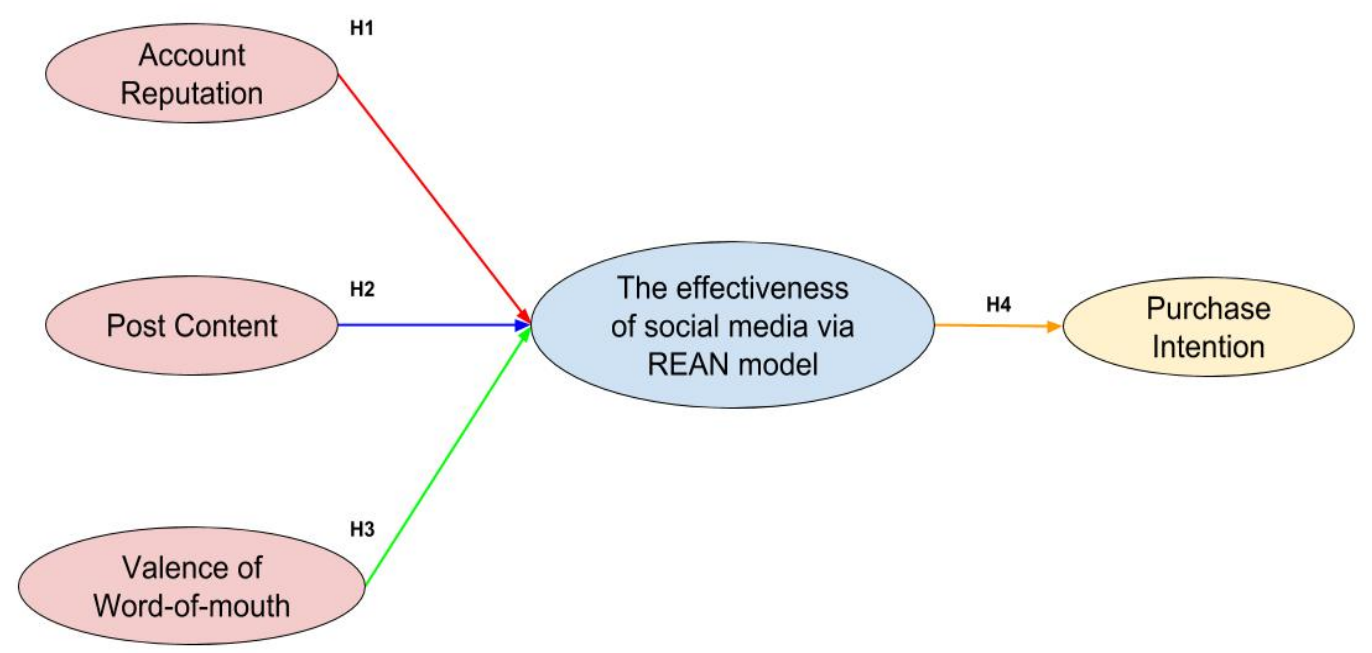

The survey research literature offers four modes: face-to-face, telephone, paper-and-pencil (postal and fax) and electronic questionnaires collect data (Visser et al. 2013, Wilson 2011). The questionnaire is widely used and valuable in primary data collection to investigate phenomena and relationships in a systematic way (Perumal 2014). The questionnaire is 
more flexible to change the questions during the process (Sekaran and Bougie 2013). The questionnaire can be categorized in self-administered and interview-administered (Saunders, Lewis and Thornhill 2016). The objective of this self-administrated questionnaire is to discover numerical insights from the target group with more significant information to explain the phenomena and verify the hypotheses.

\section{Sampling}

The online questionnaire is an increasingly popular approach to quantitative research due to the Internet (Visser et al. 2013). With the advent of the technology and the use of mobile, the use of self-administered online surveys has expanded and become more convenient (Dillman 2000). The questionnaire in this research consists of a standardized set of closedended questions for each respondent. Although the response rate is relatively low, this research technique is low cost, faster speed, wider audience reach and higher public acceptance(Wilson 2011). Moreover, the survey response rate of electronic data collection is higher than a traditional method based on participants' interests and motivation (Baruch and Holtom 2008). The accessibility of the questionnaire is higher by using the internet among the target group in millennials (Sekaran and Bougie 2013). With experimental research design, an online questionnaire is more suitable for this study, in particular, to collect cross-sectional data of all kind in an efficient way.

\section{Experiment Manipulation}

This research adopts an experimental research design (Campbell and Stanley 2015) with a primary goal to provide strong evidence for cause-and-effect relationships (Lapan and Quartaroli 2009). The static group comparison of the pre-experimental design was adopted instead of interaction effect via experiment and factorial experiment design, involving a comparison of two groups of individuals on different outcome. This research involves a randomised experimental design with the comparison group. By using a static-group comparison, the data can estimate many variables and investigate on consumers' attitudes (Szafran 2007).

This study employs three main features of Instagram in relation to previous literature, thus the interfaces of Instagram were created for a fashion brand $\mathrm{X}$ with a unisex $\mathrm{t}$-shirt. Table 1 shows the eight scenarios for the questionnaire to analyse in this research.

Table 1 Scenarios with three variables

\begin{tabular}{|l|lr|l|l|}
\hline Scenario & $\begin{array}{l}\text { Reputation } \\
\text { account }\end{array}$ & $\begin{array}{l}\text { of } \\
\text { Type of post content }\end{array}$ & $\begin{array}{l}\text { Valence of word- } \\
\text { of-mouth }\end{array}$ \\
\hline $\mathbf{1}$ & Good account & Producer-generated Content & Positive \\
\hline $\mathbf{2}$ & Good account & User-generated content & Positive \\
\hline $\mathbf{3}$ & Bad account & Producer-generated Content & Positive \\
\hline $\mathbf{4}$ & Bad account & User-generated content & Positive \\
\hline $\mathbf{5}$ & Good account & Producer-generated Content & Negative \\
\hline $\mathbf{6}$ & Good account & User-generated content & Negative \\
\hline
\end{tabular}




\begin{tabular}{|l|l|l|l|}
\hline $\mathbf{7}$ & Bad account & Producer-generated Content & Negative \\
\hline $\mathbf{8}$ & Bad account & User-generated content & Negative \\
\hline
\end{tabular}

\begin{abstract}
ANALYSIS
The data collection is a primary research survey which involved getting original data by conducting a field research. An online questionnaire was conducted through Qualtrics from $11^{\text {th }} \mathrm{JUL}$ to $31^{\text {st }}$ AUG 2018. The questionnaire was designed by closed-ended questions with numeric codes. The types of the variable will be classified as follows: the variables from the first general question in ranking, all hypothesis questions with Likert scale scores and age group are treated as "ordinal" and other variables are treated as "nominal", for example, gender, work status and race (Field 2013).

Independent samples are selected to be the appropriate statistical technique to test the hypotheses which involve the situations in which the measurement of good reputation in one sample has no effect on the measurement of a bad reputation in another sample (Wilson 2006). Table 2 reveals the result of the independent samples t-test of the mentioned three variables via REAN model. Levene's test is powerful tools to test the equality of variances and verify the assumption (Gastwirth, Gel and Miao 2009). All the sig. values in Levene's test are $>0.05$ which mean the variability in these two conditions is about the same. However, not all sig. levels are $<0.05$. Since the null hypothesis of no association is based on the significant level ( $\mathrm{sig}>0.05)$. Hence, reject $\mathrm{H}_{0}$. There is a significant effect between account reputation, and "Reach", "Activate" and "Nurture" in the REAN model as the tvalues are significant (sig. $<0.05$ ). There is no significant effect between the post content and valence of word-of-mouth and all stages in the REAN model because of all sig. levels are $>0.05$, accept the null hypothesis.
\end{abstract}

Table 2 Overall Independent Samples Test of three variables among the four stages of REAN model

\begin{tabular}{|c|c|c|c|}
\hline Variable & REAN model & Levene's Test & Sig. \\
\hline \multirow{4}{*}{$\begin{array}{l}\text { Account } \\
\text { reputation }\end{array}$} & Reach & .944 & .000 \\
\hline & Engage & .524 & .344 \\
\hline & Activate & .860 & .004 \\
\hline & Nurture & .899 & .004 \\
\hline \multirow[t]{4}{*}{ Post Content } & Reach & .962 & .719 \\
\hline & Engage & .063 & .146 \\
\hline & Activate & .761 & .475 \\
\hline & Nurture & .798 & .239 \\
\hline \multirow{4}{*}{$\begin{array}{l}\text { Valence of } \\
\text { word-of-mouth }\end{array}$} & Reach & .334 & .221 \\
\hline & Engage & .195 & .088 \\
\hline & Activate & .071 & .634 \\
\hline & Nurture & .014 & .116 \\
\hline
\end{tabular}

To conclude, there are significant relationships between account reputation and REAN model. The following graphs are analysing the correlation coefficient (r) by three variables 
in two levels. The positive coefficients indicate that the engagement level in REAN model varies in the same direction as the change of buying intention. Although all values are positive, the result implies a good engagement with higher buying intention and bad engagement with low buying intention.

Figure 3 shows that there are stronger relationships of a bad reputation on 'Reach' and 'Nurture' than a good reputation. However, the highest coefficient is 0.651 in which the strongest relationship is 'Activate' of good reputation towards 'Purchase intention'.

Figure 3

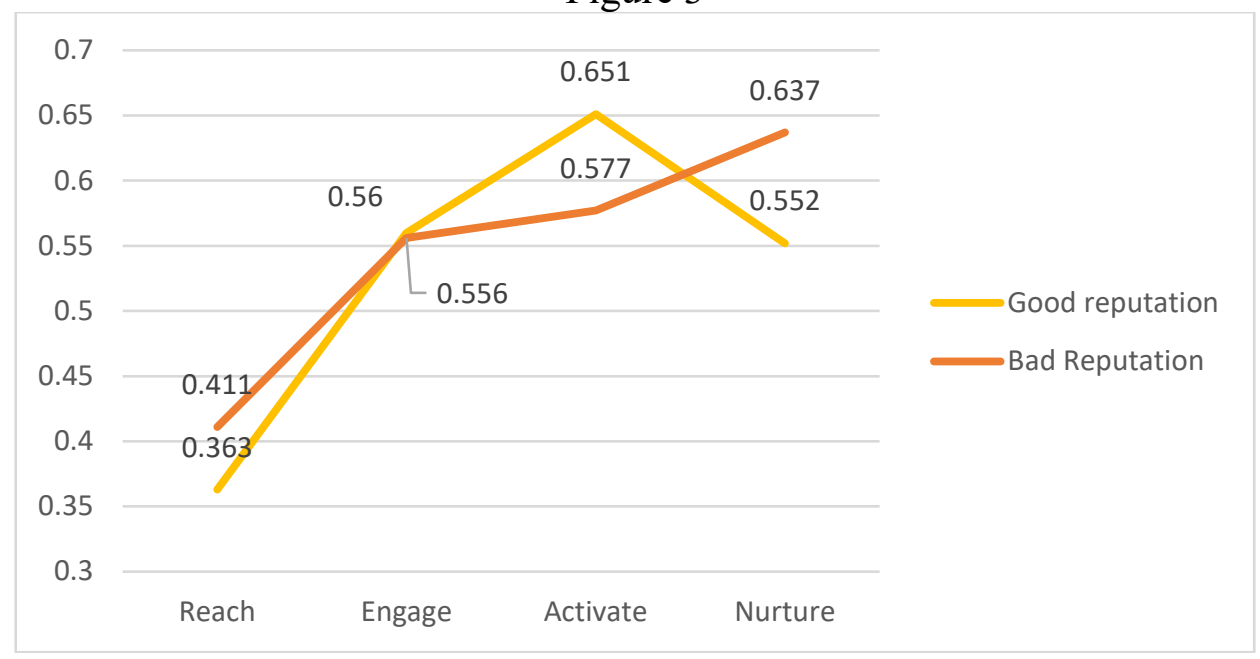

Figure 4 reveals that there are stronger relationships of user-generated content in 'Reach', 'Engage' and 'Activate' than those of producer-generated content. On the other hand, the official business content generated a stronger relationship between 'Nurture' and 'Purchase intention'. The path of producer-generated content fits the REAN model as an ongoing customer engagement model due to the increasing coefficient value.

Figure 4

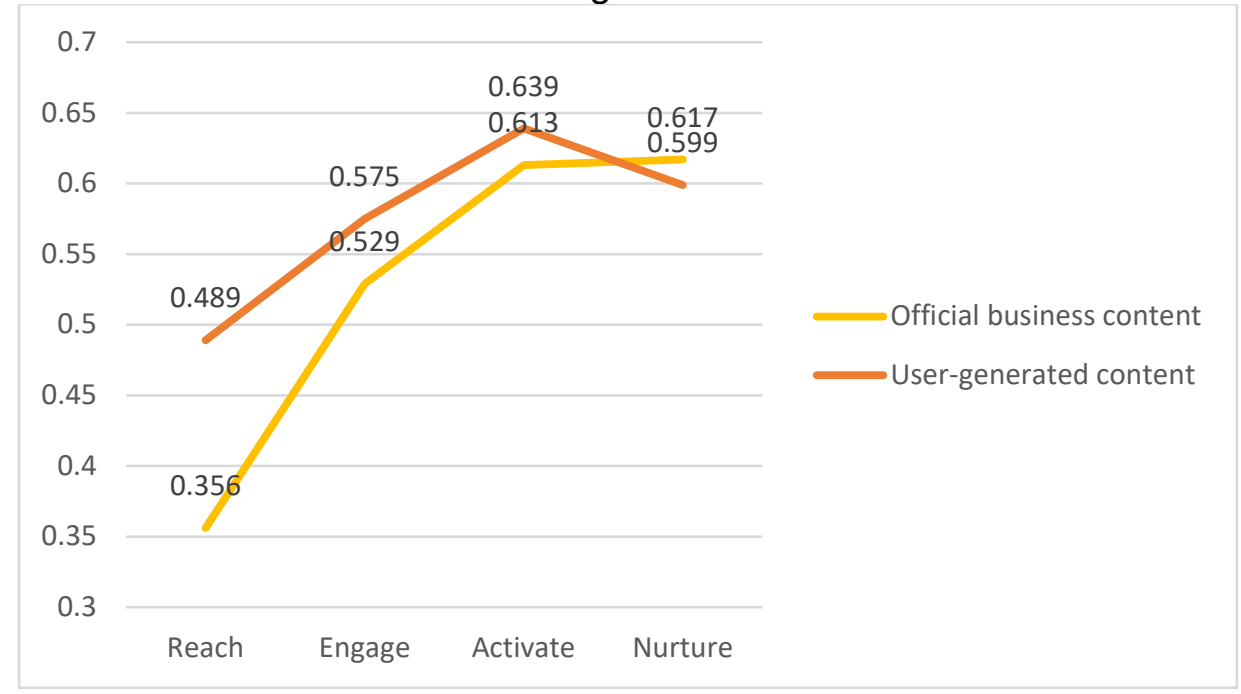


Figure 5 indicates that positive reviews have a stronger effect on the first two engagement levels in REAN model. Meanwhile, negative reviews have a stronger effect on the later engagement stages. Negative reviews do not gain much brand awareness, however, it has a greater effect on the later stage. The more negative reviews, the fewer customers willing to buy.

Figure 5

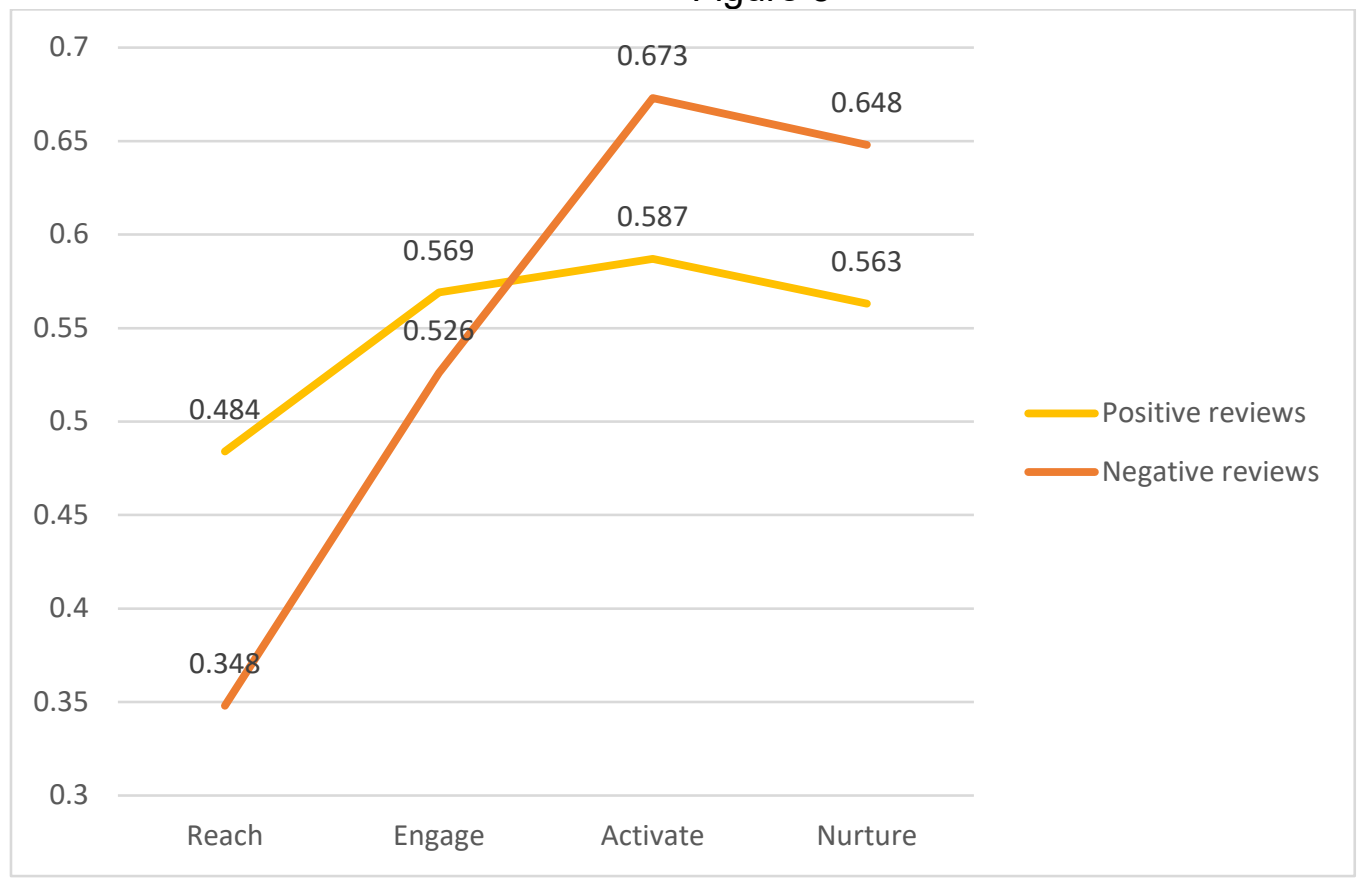

The hypotheses can be tested by exploiting the probabilistic nature of random sampling. First of all, checking the p-value of all cases. The significance of the correlation (p-value) indicates whether the hypothesis should be rejected. All $\mathrm{p}$ values below 0.05 have been bold and remarked the level of relationships. There are positive relationships between the two variables. The result reveals that the first two stages 'Reach' and 'Engage' have relatively weak to the moderate relationship. The stages of 'Activate' and 'Nurture' have a stronger relationship toward 'Purchase intention'. The highest correlation coefficients (r) has been highlighted in red font.

Table 3 Summary of all correlations

\begin{tabular}{|c|c|c|c|c|c|c|}
\hline $\begin{array}{l}\text { Case } \\
\text { No. }\end{array}$ & $\begin{array}{l}\text { Independent } \\
\text { Variable }\end{array}$ & & $\begin{array}{l}\text { Dependent } \\
\text { variable }\end{array}$ & Sig. & $\begin{array}{l}\text { Correlation } \\
\text { coefficients (r) }\end{array}$ & $\begin{array}{l}\text { Support for } \\
\text { Hypotheses }\end{array}$ \\
\hline \multirow[t]{4}{*}{1} & Reach & $\rightarrow$ & $\begin{array}{l}\text { Purchase } \\
\text { Intention }\end{array}$ & .002 & .507 & Moderate \\
\hline & Engage & $\rightarrow$ & $\begin{array}{l}\text { Purchase } \\
\text { Intention }\end{array}$ & .000 & .619 & $\begin{array}{l}\text { Moderate- } \\
\text { strong }\end{array}$ \\
\hline & Activate & $\rightarrow$ & $\begin{array}{l}\text { Purchase } \\
\text { Intention }\end{array}$ & .000 & .691 & $\begin{array}{l}\text { Relatively } \\
\text { strong }\end{array}$ \\
\hline & Nurture & $\rightarrow$ & $\begin{array}{l}\text { Purchase } \\
\text { Intention }\end{array}$ & .000 & .602 & Moderate \\
\hline
\end{tabular}




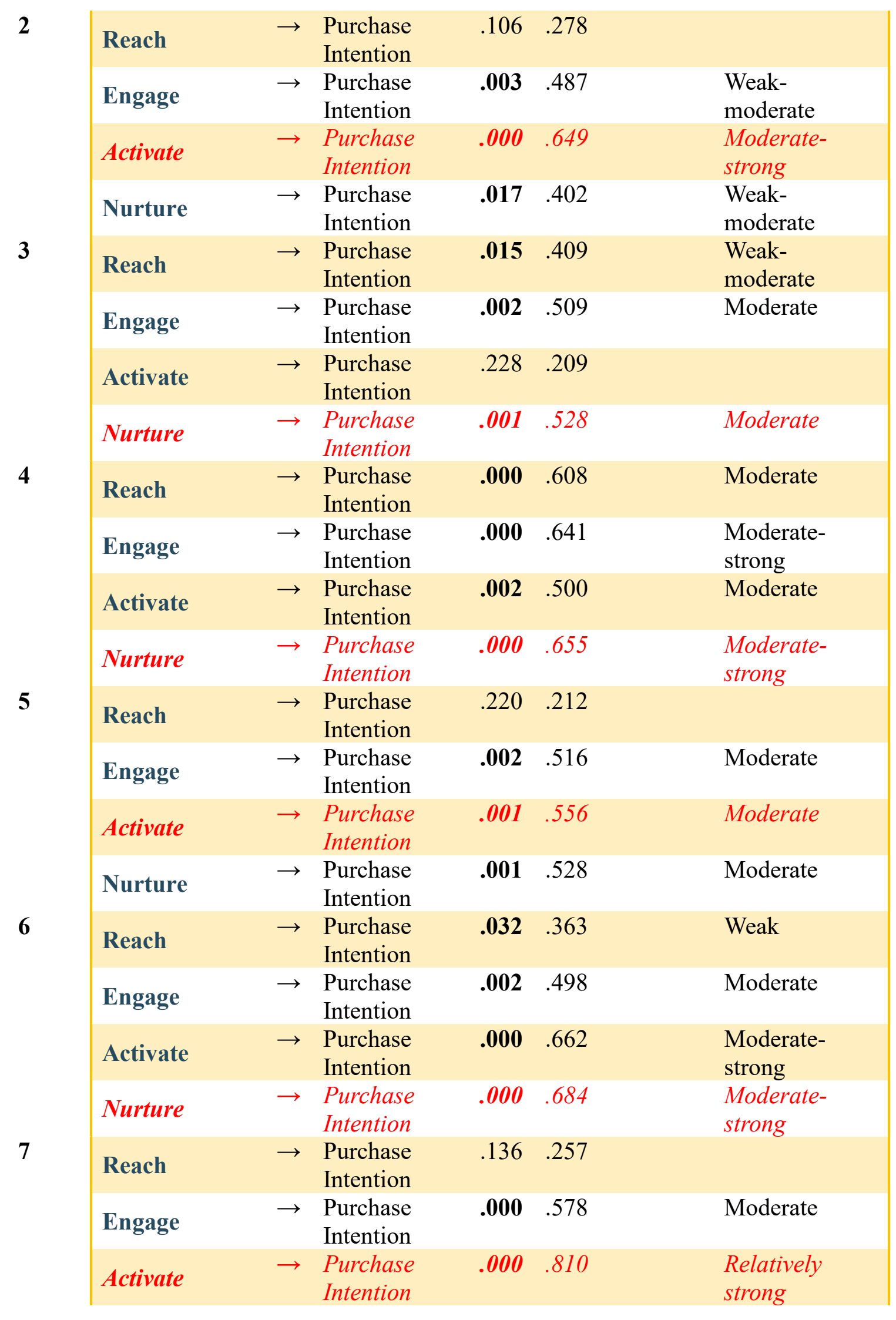




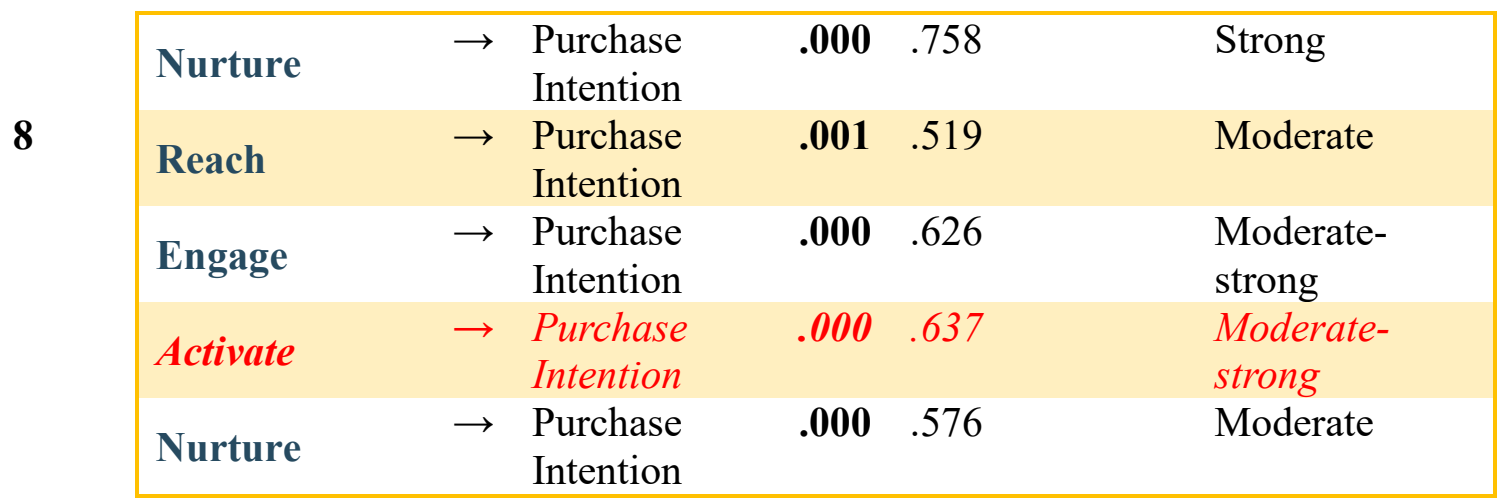

\section{CONCLUSION}

The findings represent a potentially significant contribution to knowledge in the field on the use of Instagram toward customer engagement and buying intention. Through the primary research from millennials, the findings and discussion are in relation to the research objectives. The causal relationships between the use of Instagram via REAN model and purchase intention have been proved. Nevertheless, the results provided evidence that different functions on Instagram need to be considered in developing the marketing strategy.

All four hypotheses were tested and concluded. According to the results from the independent sample test and mean value, it is interesting to find out that only account reputation has the significant effect on the REAN model $(\mathrm{H} 1)$. There are no significant relationships of the type of post content (H2) and the valence of word-of-mouth (H3) towards the engagement levels on REAN model. On the other hand, those three variables have a different effect on the engagement level in relation to buying intention. Results from a series of regression analyses indicate that customer engagement levels in REAN model by different situations are significant predictors that related to buying intention. To conclude, the best aspects of three variables in a case are good account reputation, usergenerated content and positive word-of-mouth. The presented results need have further discussion to draw overall conclusions, implications and recommendations.

The findings of this study have a number of important implications for future practice. This research aimed to provide a clear overview of the effectiveness of Instagram as a marketing tool for the fashion industry. In terms of managerial implications, Instagram has become more popular due to the visual components when targeting millennials. The first step to use Instagram is to maintain the account profile with good account reputation because of the initial impression of an Instagram account. Besides, User-generated content is more effective toward the engagement levels. Marketers should not just only provide informative business posts but also should have an interactive user-generated pot to attract customers. Besides, the brand $\mathrm{X}$ was self-created with the product as a unisex $\mathrm{t}$-shirt for this research which may irrelevant to respondents' interests. It is more important that the respondents are really looking for the actual brand and products. Marketers take explicit care of targeting customers for the brand with the help of user information. Therefore, the content will appeal to the right segment and targeted customers. The results can indicate the 
effectiveness more successful. Nevertheless, the brands should be aware of all the reviews, especially negative word-of-mouth. There are a number of important changes which need to be made. Apart from account profile, normal post content and review, the company can still create attention about the product and service by advertisement. There is still a critical need to find an effective strategy for the business. The businesses need to know more about the advertisement on Instagram to increase conversion. Marketers should also post on a regular basis to engage with customers. It is useful to state that this is not a precise measure on social media marketing and Instagram.

Notwithstanding, the limitations pointed out that the recent research has provided the new insights about the relationships between engagement level on Instagram and customer purchase intention on Instagram. Considering the current concerns about millennials and the use of Instagram in the fashion industry, the findings are regarded to be practical value. Future studies on the current topic are therefore recommended for more in-depth analysis.

\section{REFERENCE}

Anderson, E. W., 1998. Customer satisfaction and word of mouth. Journal of service research, 1(1), pp. 5-17.

Armelini, G. \& Villanueva, J., 2011. Adding Social Media to the Marketing Mix: The Power of Word of Mouth. Social Media: Are You in the Conversation?, Issue 9, pp. 2936.

Arndt, J., 1967. Role of product-related conversations in the diffusion of a new product.. Journal of Marketing Research, 4(3), pp. 291-295.

Bahtar, A. Z. \& Muda, M., 2016. The Impact of User - Generated Content (UGC) on Product Reviews towards Online Purchasing - A Conceptual Framework. Procedia Economics and Finance, 37(The Fifth International Conference on Marketing and Retailing (5th INCOMaR) 2015), pp. 337-342.

Baruch, Y. \& Holtom, B. C., 2008. Survey response rate levels and trends in organizational research. Human Relations, 61(8), pp. 1139-1160.

Brodie, R., Hollebeek, L., Jurić, B. \& Ilić, A., 2011. Customer engagement: Conceptual domain, fundamental propositions, and implications for research. Journal of Service Research, 14(3), pp. 252-271.

Buttle, F. A., 1998. Word of mouth: understanding and managing referral marketing. Journal of Strategic Marketing, 6(3), pp. 241-254.

Campbell, D. T. \& Stanley, J. C., 2015. Experimental and Quasi-Experimental Designs for Research. 1st ed. s.1.:Ravenio Books.

Chen, Y., Wang, Q. \& Xie, J., 2011. Online Social Interactions: A Natural Experiment on Word of Mouth versus Observational Learning. Journal of Marketing Research, 48(2), pp. 238-254.

Dennhardt, S., 2014. User-Generated Content and its Impact on Branding: How Users and Communities Create and Manage Brands in Social Media. 1st ed. s.1.:Springer Gabler.

Dillman, D. A., 2000. Mail and Internet Surveys: The Tailored Design Method. 2nd ed. New York: Wiley.

Feick, L. F. \& Price, L. L., 1987. The Market Maven, a Diffuser of Marketplace 
Information. Journal of Makreting, Volume 2, pp. 83-97.

Field, A., 2013. Discovering Statistics Using IBM SPSS Statistics. 4th ed. London: SAGE Publications Ltd.

Gastwirth, J. L., Gel, Y. R. \& Miao, W., 2009. The Impact of Levene's Test of Equality of Variances on Statistical Theory and Practice. Statistical Science, 24(3), pp. 343-360.

Hemley, D., 2013. 26 Tips for Using Instagram for Business. [Online] Available at: https://www.socialmediaexaminer.com/instagram-for-business-tips/ [Accessed 29 AUG 2018].

Herold, K., 2015. Impact of Word-of-mouth on Consumer Decision-Making: An Information Processing Perspective in the Context of A High-involvement Service. Lappeenranta University of Technology, s.n.

Hsu, C., Lin, J. \& Chiang, H., 2013. The effects of blogger recommendations on customers' online shopping intentions. Internet Research, 23(1), pp. 69-88.

Huete-Alcocer, N., 2017. A Literature Review of Word of Mouth and Electronic Word of Mouth: Implications for Consumer Behavior. Front Psychol, 8(1256), pp. 1-4.

Instagram, 2017. Instagram Press - Our Story. [Online] Available at: https://instagram-press.com/our-story/

[Accessed 14 NOV 2017].

Jackson, S., 2009. Cult of Analytics: Driving online marketing strategies using web analytics. 2nd ed. New York: Routledge.

Jackson, S., 2016. Cult of Analytics: Data analytics for marketing. 2nd ed. Abingdon: Routledge.

Jeon, J. O. \& Baeck, S., 2016. The effect of the valence of word-of-mouth on consumers' attitudes toward co-brands: The moderating roles of brand characteristics. Journal of Global Scholars of Marketing Science, 26(1), pp. 89-108.

Jonas, J. R. O., 2010. Source Credibility of Company - Produced and User - Generated Content on the Internet: An Exploratory Study on the Filipino Youth. Philippine Management Review, Volume 17, pp. 121-132.

Kaplan, A. \& Haenlein, M., 2010. Users of the world, unite! The challenges and opportunities of social media. Business Horizons, Volume 53, pp. 59-68.

Keller, E., 2007. Unleashing the Power of Word of Mouth: Creating Brand Advocacy to Drive Growth. Journal of Advertising Research, 47(4), pp. 448-452.

Kerpen, D., 2015. Likeable Social Media - How to Delight Your Customers, Create an Irresistible Brand, and Be Amazing on Facebook, Twitter, LinkedIn, Instagram, Pinterest, and More. 2nd ed. United States of America: Mc Graw Hill Education.

Kim, A. \& Ko, E., 2012. Do Social Media Marketing Activities Enhance Customer Equity? An Empirical Study of Luxury Fashion Brand. Journal of Business Research, 65(10), pp. 1480-1486.

Kimmel, A. J. \& Kitchen, P. J., 2014. Word of mouth and social media. Journal of Marketing Communications, 20(1-2), pp. 2-4.

Lapan, S. D. \& Quartaroli, M. T., 2009. Research Essentials: An Introduction to Designs and Practices. In: G. Belli, ed. Chapter 4: Nonexperimental Quantitative Research. United State: WILEY, pp. 59-77.

Lee, D., Hosanagar, K. \& Nair, H., 2014. The Effect of Social Media Marketing Content on Consumer Engagement: Evidence from Facebook. Stanford, INFORMS Conference. 
Lee, J. \& Lee, J.-N., 2009. Understanding the product information inference process in electronic word-of-mouth: An objectivity-subjectivity dichotomy perspective. Information \& Management, 46(5), pp. 302-311.

Miles, J., 2014. Instagram Power: Build Your Brand and Reach More Customers with the Power of Pictures. 2nd ed. United States of America: McGraw Hill Professional.

Mir, I. \& Rehman, K., 2013. Factors Affecting Consumer Attitudes and Intentions Toward User-Generated Product Content On Youtube", Management and Marketing. Management \& Marketing Challenges for the Knowledge Society, 8(4), pp. 637-654.

Namias, J., 1959. Intentions to Purchase Compared with Actual Purchases of Household Durables. Journal of Marketing, 24(1), pp. 26-30.

Nunes, R. H., Ferreira, J. B., Freitas, A. S. d. \& Ramos, F. L., 2018. The effects of social media opinion leaders' recommendations on followers' intention to buy. $R B G N$ Review of Business Management, 20(1), pp. 57-73.

OECD, 2017. Participative web: User-Created Content. France, Organisation for Economic Co-operation and Development.

Ohanian, R., 1990. Construction and Validation of A Scale to Measure Celebrity Endorser's Perceived Expertise, Trustworthiness, and Attractiveness. Journal of Advertising, 19(3), pp. 39-52.

Perumal, T., 2014. Research Methodology. In: Quantitative Research Methods. Malaysia: Open University , pp. 87-104.

Prasertsith, K., Kanthawongs, P. \& Kanthawongs, P., 2015. The Factors Affecting Purchase Intention of Fashion Accessories through Instagram. Orlando, Florida, USA, The 9th International Multi-Conference on Society, Cybernetics and Informatics (IMSCI 2015).

Purnawirawan, N., Pelsmacker, P. D. \& Dens, N., 2012. Balance and Sequence in Online Reviews: How Perceived Usefulness Affects Attitudes and Intentions. Journal of Interactive Marketing, 26(4), pp. 244-255.

Rimal, A., Fletcher, S. M. \& McWatters, K. H., 1999. Actual Purchase vs. Intended Purhase: Do consumers buy what they say?. Tennessee, the American Agricultural Economics Association.

Rodgers, S. \& Thorson, E., 2000. The interactive advertising model: How users perceive and process online advertisements. Journal of Interactive Advertising, 1(1), pp. 42-61.

Saunders, M., Lewis, P. \& Thornhill, A., 2016. Research methods for business students. 7 ed. Essex, England: Pearson Education Limited.

Sekaran, U. \& Bougie, R., 2013. Research Methods for Business: A Skill-Building Approach. 6th ed. New York: Wiley. John Willey \& Sons Ltd.

Smith, K. T., 2012. Longitudinal study of digital marketing strategies targeting Millennials. Journal of Consumer Marketing, 29(2), pp. 86-92.

Sparks, B. \& Browning, V., 2011. The impact of online reviews on hotel booking intentions and trust. Tourism Management, 32(6), pp. 1310-1323.

Szafran, R. F., 2007. Assessing Program Outcomes When Participation Is Voluntary: Getting More Out of a Static-Group Comparison. Practical Assessment, Research \& Evaluation, 12(8), pp. 1-11.

Verhellen, Y., Dens, N. \& Pelsmacker, P. d., 2013. Consumer responses to brands placed in youtube movies: The effect of prominence and endorser expertise. Journal of 
Electronic Commerce Research, 14(4), pp. 287-303.

Visser, E. \& Weideman, M., 2011. An empirical study on website usability elements and how they affect search engine optimisation. SA Journal of Information Management , 13(1), pp. 1-9.

Visser, P. S., Krosnick, J. A., Lavrakas, P. J. \& Kim, N., 2013. Survey Research. Handbook of Research Methods in Social Psych, 20(21), pp. 402-440.

Wee, C. S., 2014. Consumers Perception, Purchase Intention and Actual Purchase Behavior of Organic Food Products. Review of Integrative Business \& Economics Research, 3(2), pp. 378-397.

Wilson, A., 2006. Marketing Research - An Integrated Approach. 2nd ed. Essex: Pearson Education Limited.

Wilson, A., 2011. Marketing Reserach - An Intergrated Approach. 3 ed. UK: FT Prentice Hall. 